\title{
Dry Vs. Liquid Feeding: Growth Performance, Nutrient Digestibility and Economics in Large White Yorkshire (LWY) Grower-Finisher Pigs
}

\author{
Rajat Buragohain $^{1 *}$, Bibeka Nanda Saikia ${ }^{2}$, Arup Kumar Samanta ${ }^{1}$, Robin Bhuyan ${ }^{2}$, \\ Runjun Dowarah ${ }^{2}$, Ranjit Roychaudhury ${ }^{2}$ and Arundhuti Bora ${ }^{2}$
}

${ }^{1}$ Department of Animal Nutrition, College of Veterinary Sciences and A.H., Central Agricultural University, Selesih, Aizawl, Mizoram - 796015, India

${ }^{2}$ Department of Animal Nutrition, College of Veterinary Sciences, Assam Agricultural University, Khanapara, Guwahati, Assam - 781022, India

*Corresponding author

\section{Keywords}

Dry and liquid feeding, Growth, Nutrient digestibility FCR, LWY Pig

Article Info

Accepted:

15 July 2019 Available Online: 10 August 2019

A B S T R A C T

The study made comparative assessment of dry vs. liquid feeding on growth, nutrient digestibility and economics of grower-finisher LWY pigs. Twelve weaned piglets ( $11.45 \pm 2.42$ to $11.46 \pm 2.37 \mathrm{~kg}$, 42 -days of age) were assigned to two treatments - dry feeding (DF) and liquid feeding (LF) for 180 days. The LF was prepared by mixing basal ration with water at 1:2 $(w / w)$ immediately before feeding. No significant difference was observed for feed intake. Body weight gain was statistically insignificant in growing, but was significantly high in LF in finishing period. No significant $(\mathrm{P}>0.05)$ difference was observed for nutrient digestibility, but was comparatively better in LF than DF. There was improvement of fortnightly FCR in LF, but without any significant difference. The feed cost $/ \mathrm{kg}$ body weight gain was significantly $(\mathrm{P}<0.05)$ reduced in LF. Considering the parameters studied, it was concluded that feeding of LF might be recommended over dry feeding for grower-finisher LWY pigs.

\section{Introduction}

Piggery is an important animal husbandry activity supporting livelihood to millions of rural poor farmers, particularly the tribal communities, throughout India. The present shortfall of 0.48 million tonnes of pork or a deficit of $48.38 \%$ (DARE report, 2012-13) signifies the importance of piggery sector towards economic sustainability of the Indian farmers. With the increasing awareness created by the KVKs, State/Central Agricultural Universities through various scientific/vocational training programmes, scientific feeding has replaced the traditional backyard feeding system. In this regard, 
however, the main hindrance is the high feeding cost for the soaring prices of feed ingredients day-by-day. This has narrowed down the profit margin as feeding cost represents nearly two-third of the total production cost in piggery (Liao and Nyachoti, 2017). Therefore, enhancing feed efficiency is very crucial for remunerative pig production (Patience, 2015) which necessitates for development of a feeding strategy which will be cost-effective, but can also ensure remunerative profit to the pig farmers.

Traditionally, in intensive rearing, ration/feed and drinking water are provided separately to the pigs in separate feeding and watering troughs. However, in recent decades, feeding of ration/feed in liquid form (i.e. mixing with water at a particular ratio immediately before feeding) is gaining popularity among the pig farmers for manifold advantages. Weaned piglets adapt more easily to a diet having some liquid in the initial post-weaning stage (Choct et al., 2004). Liquid feeding also reduces feed wastage as dust, increases acidity of the diet and availability of phosphorous, improves accessibility to substrates by the digestive enzymes, and reduces viscosity of gut resulting in improvement of the feed efficiency of pigs (Brooks, 1994 and Geary et al., 1996). Therefore, considering the importance of piggery for the livelihood of the rural people, and cost-effective feeding for remunerative pig husbandry, the present study was undertaken for comparative assessment between dry and liquid feeding regimes on growth performance, nutrient digestibility and economics of grower-finisher LWY pigs under intensive system of management.

\section{Materials and Methods}

The study was conducted at the Instructional Livestock Farm Complex, College of Veterinary Sciences \& Animal Husbandry,
Central Agricultural University, Selesih, Aizawl, Mizoram as per MOU signed between Assam Agricultural University, Jorhat, Assam and Central Agricultural University, Imphal, Manipur. The study was approved by Institutional Animal Ethics Committee (Approval No. 770/ac/CPCSEA/FVSc/AAU/ IAEC/17-18/481 dated 09.08.2017).

Total 12 weaned piglets (42-days of age, body weight ranging from $11.45 \pm 2.42$ to $11.46 \pm 2.37 \mathrm{~kg}$ ) were selected and randomly assigned to two treatments (3 males and 3 females in each groups). Pigs of treatment I (designated as DF) were offered basal ration in dry form and pigs of treatment II (designated as LF) were offered liquid feed i.e. Basal ration mixed with water at 1:2 ratio (w/w) without any bacterial culture immediately before feeding to the pigs. The pigs were housed individually considering each piglet as one replicate. Feeding was done twice daily (morning 8.00 - 9.00 A.M. and evening 2.00 - 3.00 P.M.).

Four basal experimental rations were formulated as per NRC (2012) (Ration for 11$25 \mathrm{~kg}, 25-50 \mathrm{~kg}, 50-75 \mathrm{~kg}$ and $75-100 \mathrm{~kg}$ body weight of pigs). The feeding trial was conducted for 180 days. The records of daily individual feed intake and fortnightly body weight gain were recorded throughout the experiment. Two digestion trials were conducted. The first digestion trial was conducted in the growing period i.e. at the end of $17^{\text {th }}$ week of age and the $2^{\text {nd }}$ one in the finishing period i.e. at the end of $29^{\text {th }}$ week of age. For each of the digestion trial, three animals from each group were randomly selected. Daily individual feed intake and faeces voided by the animals were recorded. A suitable aliquot of faeces was taken for dry matter estimation and was stored in labelled container for further laboratory analysis. A separate aliquot of faeces mixed with sulphuric acid (1:4) was preserved for 3 days 
in previously weighed wide - mouth stoppered glass bottles for nitrogen estimation.

The samples feed and faeces were analysed for proximate principles following AOAC (2012), calcium by Talapatra et al., (1940) and phosphorous by AOAC (1975). Analysis of basal feed for fibre fraction was carried out following method of Goring and Van Soest (1970). The data generated was analysed following students' t-test adopting standard statistical procedures of Snedecor and Cochran (1994).

\section{Results and Discussion}

The ingredient and nutritional composition of the basal experimental rations are presented in table 1. All the nutrients were as per the recommended levels of NRC (2012) for grower-finisher pigs. The cost of the ration was calculated based on the feed ingredient price during the 2018-2019. As the prices of the feed ingredients were comparatively higher at Aizawl, Mizoram compared to other places of the mainland for the cost involved in transportation due to remoteness and geographical constraints, the cost (Rs./kg) of the rations were calculated to be higher.

The way the feed is delivered has great influence on intakes (Choct et al., 2004) of the post-weaning pigs. Providing a liquid diet is known to produce a regular eating pattern after weaning increasing the dry matter intakes (Russell et al., 1996). The improvement of average daily feed intake and total feed intakes during the growing and finishing period in LF might for feeding of feed and water together also reported by Thacker (1998). This might also be for reduced feed wastage and changes of physical and chemical nature of feed liquid form (Brooks and Tsourgiannis, 2003). In our present study, there was improvement of $2.10 \%$ in feed consumption during growing, $1.10 \%$ during the finishing and $1.44 \%$ in overall consumption of LF than pigs fed DF. Pedersen and Stein (2010) observed that when feed was offered in liquid form by mixing feed and water at 1:1 ratio stimulated feed consumption in the post weaning period. However, no significant $(\mathrm{P}>0.05)$ difference was observed in feed consumption during the feeding trial period between the groups.

Sustainable growth indicates efficient utilization of nutrients with better gut health and immunity of the animals. Potential growth is a continuous process and discontinuity of growth can be assumed as the reflection of external influences as the genetic make-up of the animal will be same at all the times. In the present study, total body weight gain in the growing phase was found to be higher in LF, but without any significant difference from DF. However, in the finishing period, body weight gain was significantly $(\mathrm{P}<0.05)$ higher in LF indicating the positive effect of feeding liquid feed. Improvement in growth rate under the liquid feeding regime might be for improvement in feed intake and digestibility of nutrients in LF compared to DF. This might also be for reduced feed wastage and improvement of accessibility of the substrates to digestive enzymes and reduced viscosity of the gut for feeding of LF (Brooks, 1994 and Geary et al., 1996).

The body weight at the end of $6^{\text {th }}$ fortnight were recorded as 44.08 \pm 1.04 and $46.00 \pm 2.29$ $\mathrm{kg}$ and at the end of $12^{\text {th }}$ fortnight were recorded as $91.55 \pm 1.55$ and $96.53 \pm 3.04 \mathrm{~kg}$, respectively in LF and DF indicating a $6.23 \%$ improvement in overall body weight gain for feeding of feed in liquid form to the pigs. Kim et al., (2001) also observed $21 \%$ higher body weight and $44 \%$ greater average daily gain in body weight in pigs fed liquid feed than pigs fed dry pellets (Table 2 and 3 ). 
Table.1 Ingredient (\%) and nutritional composition (on DM basis) of experimental ration

\begin{tabular}{|c|c|c|c|c|}
\hline \multirow[t]{2}{*}{ Name of Ingredient } & \multicolumn{4}{|c|}{ Experimental Ration } \\
\hline & $\begin{array}{l}\text { Ration I } \\
(11-25 \text { kg) }\end{array}$ & $\begin{array}{c}\text { Ration II } \\
(25-50 \mathrm{~kg})\end{array}$ & $\begin{array}{l}\text { Ration III } \\
(50-75 \mathrm{~kg})\end{array}$ & $\begin{array}{c}\text { Ration IV } \\
(75-100 \mathrm{~kg})\end{array}$ \\
\hline \multicolumn{5}{|c|}{ Ingredient composition (\%) } \\
\hline Yellow Maize & 52.45 & 59.06 & 62.00 & 66.00 \\
\hline Wheat Bran & - & - & 6.00 & 8.00 \\
\hline Soyabean meal & 27.00 & 21.00 & 15.00 & 11.00 \\
\hline De-oiled ground nut cake (SE) & 8.00 & 8.00 & 7.00 & 5.60 \\
\hline Fish Meal & 5.00 & 5.00 & 4.00 & 3.00 \\
\hline L-Lysine & 0.50 & 0.40 & 0.30 & 0.30 \\
\hline DL- Methionine & 0.05 & 0.04 & - & - \\
\hline Vegetable oil & 4.00 & 3.50 & 3.20 & 3.60 \\
\hline Iodised Salt & 0.50 & 0.50 & 0.50 & 0.50 \\
\hline Vitamin-Min premix & 2.50 & 2.50 & 2.00 & 2.00 \\
\hline Total & 100 & 100 & 100 & 100 \\
\hline Cost (Rs./kg) & 40.31 & 35.45 & 32.41 & 30.55 \\
\hline \multicolumn{5}{|c|}{ Nutritional composition (\% on DM basis) } \\
\hline Dry matter $(\%)$ & 89.98 & 89.23 & 89.55 & 89.34 \\
\hline Crude Protein (\%) & 22.52 & 19.49 & 17.26 & 15.22 \\
\hline Ether Extract (\%) & 4.84 & 3.28 & 3.25 & 4.67 \\
\hline Crude Fibre (\%) & 3.42 & 4.02 & 4.11 & 4.53 \\
\hline Total Ash (\%) & 9.15 & 8.81 & 9.49 & 8.37 \\
\hline Nitrogen Free Extract (\%) & 60.07 & 64.40 & 65.89 & 67.21 \\
\hline Organic Matter (\%) & 90.85 & 91.19 & 90.51 & 91.63 \\
\hline Acid Insoluble Ash (\%) & 0.98 & 0.85 & 1.36 & 1.22 \\
\hline Neutral Detergent Fibre (\%) & 14.86 & 15.40 & 19.36 & 23.04 \\
\hline Acid Detergent Fibre (\%) & 4.87 & 3.45 & 4.99 & 4.97 \\
\hline Hemi-cellulose (\%) & 9.99 & 11.95 & 14.37 & 18.06 \\
\hline Calcium (\%) & 3.34 & 3.12 & 2.96 & 2.97 \\
\hline Total Phosphorous (\%) & 0.87 & 0.75 & 0.60 & 0.79 \\
\hline Energy* (Kcal ME/kg) & 3332.28 & 3315.93 & 3266.00 & 3272.88 \\
\hline Lysine* (\%) & 1.37 & 1.16 & 0.93 & 0.81 \\
\hline Methionine* $(\%)$ & 0.48 & 0.45 & 0.37 & 0.34 \\
\hline
\end{tabular}


Table.2 Growth performance of LWY pigs on dry and liquid feeding

\begin{tabular}{|c|c|c|c|}
\hline \multirow[t]{2}{*}{ Parameter } & \multicolumn{2}{|c|}{ Treatment Group } & \multirow{2}{*}{ t/p value } \\
\hline & DF & $\mathbf{L F}$ & \\
\hline \multicolumn{4}{|c|}{ Growing Phase } \\
\hline Average daily feed intake (kg) & $1.132 \pm 0.02$ & $1.156 \pm 0.05$ & $0.47 / 0.65$ \\
\hline Total feed intake (kg) & $101.87 \pm 1.55$ & $104.01 \pm 4.25$ & $0.47 / 0.65$ \\
\hline Initial body weight (kg) & $11.45 \pm 0.97$ & $11.46 \pm 0.98$ & $<0.001 / 0.99$ \\
\hline Body weight at $6^{\text {th }}$ fortnight $(\mathrm{kg})$ & $44.08 \pm 1.04$ & $46.00 \pm 2.29$ & $0.76 / 0.47$ \\
\hline Total body weight gain (kg) & $32.63 \pm 1.31$ & $34.54 \pm 1.40$ & $0.99 / 0.34$ \\
\hline Feed conversion ratio $(\mathrm{FCR})$ & $3.16 \pm 0.17$ & $3.01 \pm 0.07$ & $0.76 / 0.47$ \\
\hline \multicolumn{4}{|c|}{ Finishing phase } \\
\hline Average daily feed intake (kg) & $2.266 \pm 0.02$ & $2.291 \pm 0.08$ & $0.31 / 0.77$ \\
\hline Total feed intake (kg) & $203.97 \pm 1.72$ & $206.22 \pm 7.18$ & $0.31 / 0.77$ \\
\hline Body weight at $7^{\text {th }}$ fortnight $(\mathrm{kg})$ & $51.23 \pm 1.18$ & $53.19 \pm 2.49$ & $0.71 / 0.50$ \\
\hline Body weight at $12^{\text {th }}$ fortnight $(\mathrm{kg})$ & $91.55 \pm 1.15$ & $96.53 \pm 3.04$ & $1.53 / 0.16$ \\
\hline Total body weight gain $(\mathbf{k g})$ & $47.47^{\mathrm{a}} \pm 0.79$ & $50.53^{b} \pm 0.81$ & $2.71 / 0.02 *$ \\
\hline Feed conversion ratio (FCR) & $4.30 \pm 0.08$ & $4.08 \pm 0.08$ & $1.99 / 0.08$ \\
\hline \multicolumn{4}{|c|}{ Overall } \\
\hline Total feed intake (kg) & $305.83 \pm 2.16$ & $310.22 \pm 11.33$ & $0.38 / 0.71$ \\
\hline Total body weight gain & $80.09 \pm 0.94$ & $85.08 \pm 2.12$ & $2.15 / 0.06$ \\
\hline Feed conversion ratio (FCR) & $3.82 \pm 0.07$ & $3.64 \pm 0.05$ & $2.06 / 0.07$ \\
\hline Feed cost/kg gain $(\mathbf{R s} . / \mathrm{kg})$ & $128.36^{\mathrm{a}} \pm 2.82$ & $120.43^{b} \pm 1.67$ & $2.41 / 0.04 *$ \\
\hline
\end{tabular}

Means bearing different superscripts $(\mathrm{a}, \mathrm{b})$ in a row differs significantly $(* * \mathrm{P}<0.01, * \mathrm{P}<0.05)$

Table.3 Apparent Nutrient Digestibility of pigs on dry and liquid feeding

\begin{tabular}{|c|c|c|c|}
\hline \multirow[t]{2}{*}{ Digestibility Co-efficient } & \multicolumn{2}{|c|}{ Treatment group } & \multirow[t]{2}{*}{ t/p-value } \\
\hline & DF & NFLF & \\
\hline \multicolumn{4}{|c|}{ Growing Phase } \\
\hline Dry matter (DM) & $74.77 \pm 2.03$ & $75.55 \pm 0.91$ & $0.35 / 0.74$ \\
\hline Crude Protein (CP) & $78.38 \pm 2.51$ & $79.43 \pm 1.99$ & $0.33 / 0.76$ \\
\hline Ether extract (EE) & $48.60 \pm 1.37$ & $51.10 \pm 2.59$ & $0.85 / 0.45$ \\
\hline Crude fibre CF) & $51.03 \pm 1.82$ & $51.63 \pm 4.93$ & $0.11 / 0.92$ \\
\hline Nitrogen Free Extract (NFE) & $78.02 \pm 2.70$ & $80.79 \pm 1.59$ & $0.88 / 0.43$ \\
\hline Organic matter (OM) & $77.01 \pm 1.77$ & $77.52 \pm 0.95$ & $0.25 / 0.81$ \\
\hline \multicolumn{4}{|c|}{ Finishing Phase } \\
\hline Dry matter (DM) & $81.53 \pm 1.69$ & $82.06 \pm 1.78$ & $0.22 / 0.84$ \\
\hline Crude Protein (CP) & $81.65 \pm 1.77$ & $82.06 \pm 1.72$ & $0.16 / 0.88$ \\
\hline Ether extract (EE) & $50.44 \pm 2.26$ & $50.10 \pm 1.50$ & $0.12 / 0.91$ \\
\hline Crude fibre CF) & $47.50 \pm 4.78$ & $46.75 \pm 1.44$ & $0.15 / 0.89$ \\
\hline Nitrogen Free Extract (NFE) & $86.38 \pm 1.24$ & $87.91 \pm 1.16$ & $0.89 / 0.42$ \\
\hline Organic matter $(\mathrm{OM})$ & $83.21 \pm 1.55$ & $84.13 \pm 1.53$ & $0.42 / 0.69$ \\
\hline
\end{tabular}


No significant differences $(\mathrm{P}>0.05)$ were observed for apparent digestibility of nutrients in both the growing and finishing periods. However, positive trends were observed for nutrient digestibility with numerically higher values in LF fed-pigs than the DF fed-pigs both in the growing and finishing periods. This improvement might be for physical changes of the diet for offering feed in liquid form as also reported by Tonheim et al., (2007). Insignificant effect of feeding liquid feed on nutrient digestibility was also reported by Han et al., (2006) in growing crossbred (Landrace X Yorkshire) pigs.

The feed conversion ratio (FCR) calculated as the ratio of total feed consumed $(\mathrm{kg})$ divided by total body weight gain $(\mathrm{kg})$ was found to be comparatively better in LF than the DF. The feed cost per kg gain in body weight was calculated as Rs. 128.36 \pm 2.82 and Rs. $120.43 \pm 1.67$, respectively for $\mathrm{LF}$ and $\mathrm{DF}$ indicating significantly $(\mathrm{P}<0.05)$ reduced feeding cost for feeding feed in liquid form. Jensen and Mikkelsen (1998) also reported $4.4 \%$ improvement in weight gain and $6.9 \%$ improvement in feed efficiency with the feeding of liquid feed.

From the findings of the study, it was concluded that as improvements were observed in feed consumption, apparent nutrient digestibility, growth rate, FCR and feed cost/kg gain in body weight in LF than the DF, offering feed in liquid form $(1: 2 \mathrm{w} / \mathrm{w})$ might be advocated instead of conventional dry feeding regime to LWY grower-finisher pigs.

\section{Conflict of interest}

There is no any conflict of interest.

\section{Acknowledgement}

The authors are thankful to the ViceChancellor, Central Agricultural University,
Imphal, Manipur for financial support and laboratory facilities to carry out the research work successfully.

\section{References}

AOAC, 1975. Official methods of Analysis. Association of Official Analytical Chemists. $12^{\text {th }}$ Edition, Washington D.C.

AOAC, 2012. Official Methods of Analysis of AOAC International, $19^{\text {th }}$ Edition, AOAC International, Gaithersburg, Maryland, USA.

Brooks, P.H., 1994. Water - forgotten nutrient and novel delivery system. In: Biotechnology in the feed industry Proc. Of Alltech's $10^{\text {th }}$ Annual Symposium, (Eds. TP, Lyons, KA, Jaques, Nottingham University Press, UK, 211-234.

Brooks, P.H., and Tsourgiannis, C.A. 2003. Factors affecting the voluntary feed intake of the weaned pig. In: Pluske, J.R.; Le Dividich, J. and Verstegen, M.W.A. (Eds.). Weaning the Pig, Concepts and Consequences. Wageningen Academic Publishers, Wageningen, The Netherlands, 81-116.

Choct, M., E.A.D. Selby, D.J. Cadogan, and Campbell, R.G. 2004. Effect of liquid to feed ratio, steeping time, and enzyme supplementation on the performance of weaner pigs. Austr. J. Agric. Res. 55: 247-252.

Geary, T.M., P.H. Brooks, D.T. Morgan, A. Campbell and Russell, P.J. 1996. Performance of weaner pigs fed $a d$ libitum with liquid feed at different dry matter concentrations. J. Sci. Food Agric. 72:17-24.

Goering, H.K. and Van Soest, P.J. 1970. Forage fibre analysis: apparatus, reagents, procedures and some applications. U.S. Dept. of Agri. Agri. Handbook. 379. 
Han, Yung-Keun, P.A. Thacker and Yang, Joo-Sung. 2006. Effects of the duration of liquid feeding on performance and nutrient digestibility in weaned Pigs. Asian-Aust. J. Anim. Sci. 19(3): 396401.

Jensen, B.B. and Mikkelsen, L.L. 1998. Feeding liquid diets to pigs. In: Garnsworthy, P.C. and Wiseman. J. (Eds.). Recent Advances in Animal Nutrition, published by Nottingham University Press, Nottingham, UK. 107126.

Kim, J. H., K.N. Heo, J.I. Odle, K. Han and Harrell, R. J. 2001. Liquid diets accelerate the growth of early-weaned pigs and the effects are maintained to market weight. Journal of Animal Science. 79: 427-434.

Liao, S.F. and Nyachoti, M. 2017. Using probiotics to improve swine gut health and nutrient utilization. Animal Nutrition. 3: 331-343.

NRC, 2012. National Research Council, Nutrient requirement of pigs, $12^{\text {th }}$ Eds., National Academy Press, Washington, DC.

Patience, John, F. Rossoni-Serão, C. Mariana and Gutiérrez, Néstor A. 2015. A review of feed efficiency in swine: biology and application. Journal of Animal Science and Biotechnology. 6: 33-42.
Pedersen, C. and Stein, H.H. 2010. Effects of liquid and fermented liquid feeding on energy, dry matter, protein and phosphorus digestibility by growing pigs. Livest. Sci. 134: 59-61.

Russell, P.J., T.M. Geary, P.H. Brooks and Campbell, A. 1996. Performance, water use and effluent output of weaner pigs fed ad libitum with either dry pellets or liquid feed and the role of microbial activity in liquid feed. Journal of the science of food and agriculture. 72: 816.

Snedecor, G.W. and Cochran, W.G. 1994. Statistical Methods, 8th Ed., Oxford and IBH Publishing Company, New Delhi, India.

Talapatra, S.K. S.C. Ray and Sen, K.C. 1940. Estimation of $\mathrm{P}, \mathrm{Cl}, \mathrm{Ca}, \mathrm{Na}$, and $\mathrm{K}$ in food stuffs. Indian Journal of Veterinary Science and Animal Husbandry. 10: 243-246.

Thacker, P. A. 1998. Nutritional requirements of suckling and early weaned pigs. Proc. 8th World Conf. Anim. Prod. Seoul, Korea, pp 312-334.

Tonheim, S. K., A. Høgøy Nordgreen, I.K. Hamre and Rønnestad I. 2007. In vitro digestibility of water-soluble protein fractions of some common fish larval feeds and feed ingredients. Aquaculture. 262: 426-435.

\section{How to cite this article:}

Rajat Buragohain, Bibeka Nanda Saikia, Arup Kumar Samanta, Robin Bhuyan, Runjun Dowarah, Ranjit Roychaudhury and Arundhuti Bora. 2019. Dry Vs. Liquid Feeding: Growth Performance, Nutrient Digestibility and Economics in Large White Yorkshire (LWY) GrowerFinisher Pigs. Int.J.Curr.Microbiol.App.Sci. 8(08): 2019-2025. doi: https://doi.org/10.20546/ijcmas.2019.808.235 